\title{
Recommendations to Improve the Usability of Mobile Learning for Preschool Teachers in Africa: A Systematic Scoping Review
}

\author{
Monique de Wit ${ }^{*}$ and Nicola Ann Plastow \\ Stellenbosch University, Stellenbosch, South Africa \\ https://orcid.org/0000-0001-8299-5707 \\ https://orcid.org/0000-0002-3536-9129
}

\begin{abstract}
Poor quality preschool teacher training is a significant contributor to children not achieving school readiness. With technological development, electronic and mobile learning offer accessible and affordable options for this training, however, there is a lack of design evidence for the African context. This interdisciplinary education- and computer-science study aims to provide evidence-based recommendations for improving the usability of mLearning modules for preschool teachers in Africa. A scoping review guided by Arksey and O'Malley's framework, the PRISMA reporting guidelines for scoping reviews, and Levac et al. guidelines, was conducted. Databases searched included Africa Wide Information, ERIC, CIHNAL, and Academic Search Premier. Two researchers completed a blind-review process for article inclusion and framework analysis, using 10 usability attributes with inductive grouping of data under each attribute to form sub-categories. Overlapping themes were coded to formulate usability recommendations within WeftQDA. The search yielded 909 articles and, after title and abstract screening, 123 were selected for full text review. Seventeen articles $(n=17)$ met the inclusion criteria and were included in the final review. All studies included an African partner, and largely included part-time learning for degree purposes and professional development using mLearning, eLearning, and videos. Nineteen recommendations were developed to improve the usability of mLearning training applications for preschool teachers in Africa, with contextual relevance emerging as a new usability attribute. Development of mLearning training modules for preschool teachers in Africa should include user centred design, heuristic evaluation and usability assessment, to ensure the sustainability of both mLearning and change in classroom teaching practices.
\end{abstract}

Keywords: usability; mobile learning; design; teacher training; Africa

* Corresponding author: Monique de Wit, moniquedw@sun.ac.za 


\section{Introduction}

School readiness is a pivotal point in predicting later success in life (Heckman \& Karapakula, 2019; Mashburn et al., 2008; Ramey \& Ramey, 2004). While many factors contribute to school readiness, poor or absent teacher training is a key reason why children do not have the necessary foundation knowledge and skills for entering primary school, even though they attend some form of early childhood development or preschool program (Atmore et al., 2012; Manning et al., 2017; Ramey \& Ramey, 2004). Only 20\% of Kindergarten/grade R teachers in South Africa are well qualified, whereas roughly a third have not successfully completed grade 12, the final year of high school (Department of Basic Education, 2018; Hannaway et al., 2018). In Zimbabwe, only $28.3 \%$ of early childhood teachers are qualified teachers (Chikwiri \& Musiyiwa, 2017). There is a need within the African context to provide guidelines and training to teachers, who themselves may have low levels of education, that is affordable, accessible and user-friendly. This may improve the quality of the programs offered to young children preparing to start their schooling.

Although there was a need for improved teacher training before the COVID-19 pandemic, one consequence of the pandemic is the shift to online learning for professional development. According to Smit et al. (2021), the most commonly reported needs of preschool teachers in low-resource settings were related to training and access to knowledge. Mobile learning, or mLearning, is a potential tool for addressing the challenge of making quality teacher training more widely accessible. Learning online, or eLearning, refers to a learning method that uses information and communication technologies to support learning ubiquitously and promotes the acquisition and use of knowledge. mLearning includes learning on mobile devices, wirelessly and on the move (Park, 2011). When considering the development of accessible teaching modules, mobile penetration of the region must be considered. According to the GMSA (2020) Mobile Economy Sub-Saharan Africa 2020 Report, there were 477 million unique mobile subscribers in SubSaharan Africa at the end of 2020, equivalent to a penetration rate of $45 \%$ of the total population. This means that most adults in Africa have access to a mobile device within their household.

An increasing number of institutions are developing eLearning options. However, these need to be properly designed and tested. When assessing eLearning or mLearning resources, it is important to evaluate the effectiveness of these resources in reaching learning outcomes, through heuristic evaluation and usability testing (Davids et al., 2013). Heuristic evaluation refers to experts reviewing the application against a predetermined set of generally accepted principles, to identify usability issues (Dumas \& Salzman, 2006). Similarly, a study conducted in Malaysia (Taat \& Francis, 2020), identified usability as one of the factors that influence student-teachers' acceptance of eLearning. A usability study is the assessment of the collective usability of an application through various assessment methods, by experts or by end-users, and is especially suggested for eLearning (Davids et al., 2015). Usability studies are one step in the design cycle of designing, testing, implementing results, and repeating the cycle until design and usability goals are met (Davids et al., 2011). 
Usability refers to the extent to which a product can be used, by the intended enduser, to achieve predetermined goals with effectiveness, within his or her context (International Organization for Standardization [ISO], 2011). Various attributes collectively refer to the usability of an application or program. Zhang and Adipat (2005) suggested a framework of attributes based on those most frequently assessed during usability studies of mobile applications. The ISO standards for systems and software quality (ISO, 2011) also includes various attributes, like accessibility, when referring to usability. The predetermined framework used in this study, when referring to usability, collectively consists of learnability, efficiency, memorability, errors, satisfaction, effectiveness, simplicity, comprehensibility, learning performance and accessibility (ISO, 2011; Zhang \& Adipat, 2005).

The aim of this research was to establish design and usability recommendations specifically for mLearning modules, to train preschool teachers and day care providers in Africa, through a scoping review of the current literature. The objectives of this study, guided by Arksey \& O'Malley (2005), were to:

1. Summarize and map the available peer reviewed literature on the usability of electronic and mLearning for preschool teachers and day care providers in Africa in the last 10 years,

2. Identify research gaps in the field, and,

3. Make recommendations for future usability studies for mLearning of preschool teachers and day care providers in Africa.

\section{Method}

The methodological framework for completing the systematic scoping review used for this study was guided Arksey and O'Malley (2005), and supplemented by Levac et al. (2015). The PRISMA extension for scoping reviews (PRISMA-ScR): Checklist and explanation (Tricco et al., 2018), was used to complete the reporting of the protocol and results. The protocol for this scoping review was published in the South African Journal of Occupational Therapy (De Wit \& Plastow, 2021).

The research question for this systematic scoping review was 'What is known about the usability of eLearning and mLearning interventions, that improve the knowledge, skills and attitudes among day care providers in Africa, to promote early childhood development of 3-6-year-olds?' A search was conducted in serval databases, including ERIC, CIHNAL, Africa-Wide Information, and Academic Search Premier using the predetermined keywords, developed in consultation with a librarian. These keywords included (in order of inclusion importance):

1. "early childhood development" OR preschool OR teacher OR day care

2. train* OR teach* OR learn*

3. e-learning OR mLearning OR online OR mobile

4. Africa OR LMIC

The initial search string included the term "usability", however, no articles were found using usability in combination with the above search terms. The absence of any previously published usability studies for online learning for teachers or day care providers in Africa or in low- and middle-income countries (LMIC) points to a significant gap. Focus was, therefore, shifted to identifying ways to improve the usability of mLearning applications for preschool teachers and day care providers 
in Africa, based on existing studies of online training of teachers in Africa. Literature from peer reviewed journals, published in English from January 2009 to November 2019, was included. Articles were included if they reported on an online learning component and the training of teachers in Africa. Title screening of the articles was conducted by one reviewer, then abstract and full text screening was completed by two reviewers. Technology journals were hand searched using the same parameters and keywords, and additional articles were selected for abstract screening. Only those that met the inclusion criteria were included. Disagreements on inclusion were resolved through discussion.

Once articles were selected, data was extracted on article characteristics, study population, and methodology. Article characteristics included the date of publication and source of publication. Study population was summarised to included geographical area, teaching context, number of participants, training program, age of children they are teaching, level of previous teacher training and type of program that participants are currently engaging in. Methodology characteristics considered included method (qualitative, quantitative or mixed methods), methodology (research design), level of evidence (Merlin et al., 2009), and whether eLearning, mLearning or video were the predominant teaching method.

Data on publication metrics, participants, and methodology were charted using predetermined categories, which were modified when required during data capture. Analysis was completed dependant on the type of variable. Scale variables were analysed using mean and standard deviations, ordinal variables using the median and range and categorical variables using frequencies. The National Health and Medical Research Council (NHMRC) Designation of Levels of Evidence (Merlin et al., 2009), a revised common standard against which an initial quality assessment of a research study can be done, was used to identify current gaps and strengths in the body of research.

Framework analysis is a highly structured approach for analysing and organising qualitative data and is largely a deductive approach. However, it allows for the flexibility to add any themes as they emerge from the data (Barnett-Page \& Thomas, 2009). During the framework analysis, each of the 17 articles were read in full to familiarise the researchers with the content. Any findings or recommendations related to usability in each article were extracted verbatim and imported into a separate MS Word document for each article. This data was then coded using a predetermined framework of 10 attributes of usability. The nine attributes of usability suggested in Zhang and Adipat's (2005) framework, including learnability, effectiveness, efficiency, comprehensibility, satisfaction, learning performance, simplicity, errors and memorability, were included in the predetermined framework for this study. The final attribute included in this framework was accessibility, which the current ISO standards for usability (ISO, 2011) also described as an important aspect of usability. All 10 attributes of usability in the framework are considered from the user's perspective when using an application. 
The extracted recommendations were then coded using these 10 attributes as a predetermined framework using Weft QDA, a qualitative data analysis package. During the analysis, one additional attributes, namely contextual relevance, emerged and was added to the framework, and thus, collectively formed 11 attributes of usability. All 11 attributes were represented, with substantial overlap in the recommendations across categories. Similar recommendations were then inductively grouped together from different studies into subcategories to formulate recommendation statements for usability, rather than each attribute separately. These recommendations may inform the design of mLearning applications for preschool teachers and day care providers.

\section{Results}

The keywords search generated 909 titles, which were screened for inclusion. As illustrated in Figure 1, after title screening, 236 abstracts, plus 4 additional articles from a search of the technology journals, were uploaded to Covidence, an online tool for managing scoping and systematic reviews. From the abstract review, 123 full text articles were selected. Following full text review, 17 articles, which met all the inclusion criteria for this scoping review, were included for data extraction. The reference lists of each included article were then used to complete a title screen against the same inclusion/exclusion criteria, as generated for this review. No new articles were added for abstract screening.

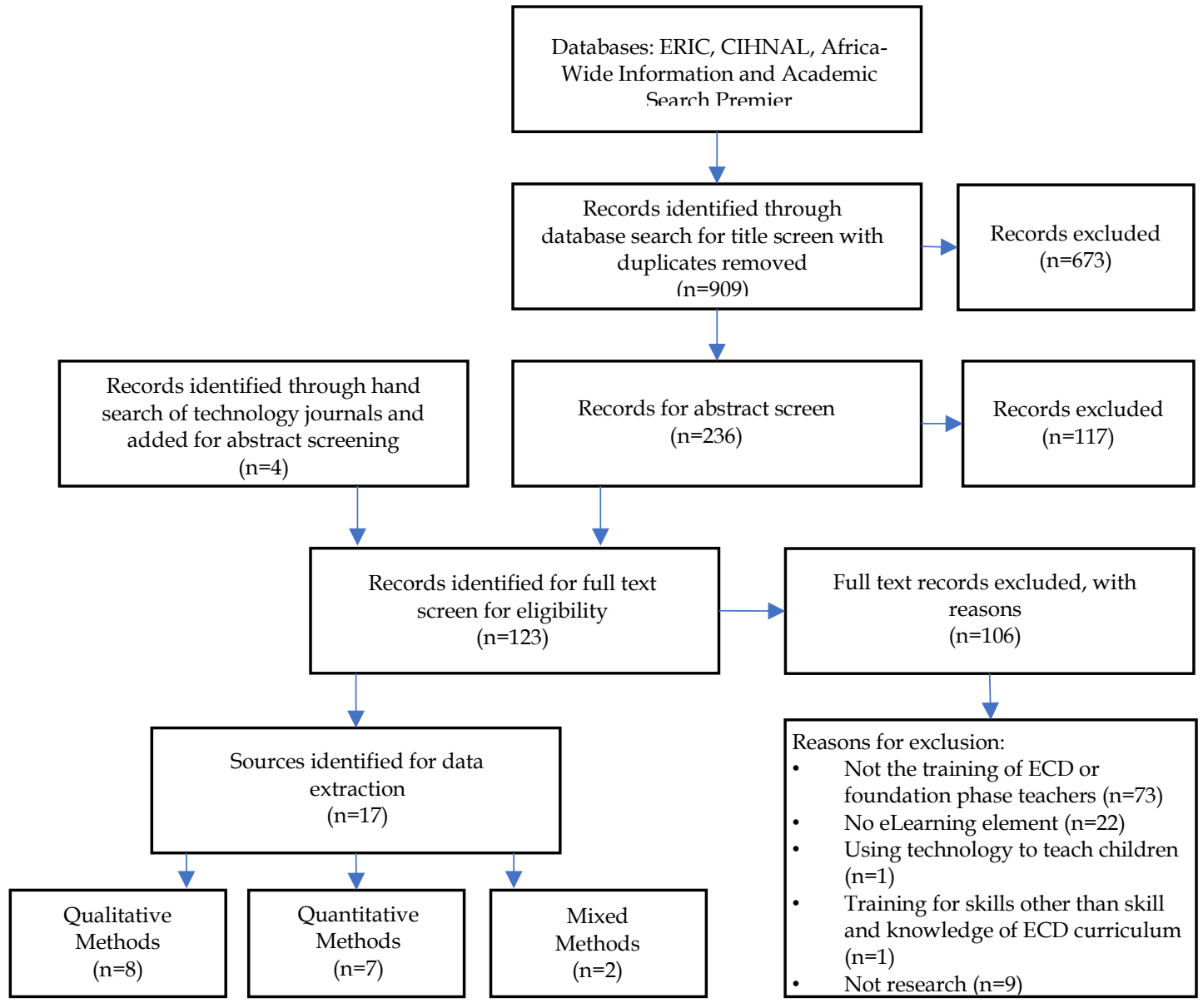

Figure 1: PRISMA diagram for the scoping review process 
Seventeen articles, which met all inclusion criteria, were identified for this review and are summarised in Table 1. Articles were published between January 2009 to November 2019 with over $70 \%(n=12)$ published 2016 or later. About half of the studies were conducted in South Africa $(n=9)$, four studies were conducted in other African countries only (Uganda, n=1, Nigeria, $n=1$ and Kenya, n=2). One study included a review and data gathered from Ghana and other non-African LMICs. All studies included at least one African partner.

Almost $18 \%(n=3)$ of the studies were conducted explicitly in resourced constrained settings, while the remainder $(n=14)$ were unreported. The number of participants ranged from 11 to 332, with a median of 48.5 participants. As with professional development programs, $82 \%(n=14)$ of the training programs were part-time participation, while $12 \%(n=2)$ were full-time and the rest $(n=1)$ were unreported. The available research on eLearning of teachers of 3-6-year-olds was found to be very limited. Only one article included teachers of 3-6-year-olds exclusively, while the remainder $(n=16)$ included the teaching of 6 -year-olds, however, had age ranges of up to 18 years. Teacher qualification included student teachers $(n=3 ; 18 \%)$, novice teachers $(n=1 ; 6 \%)$, mixed qualification group $(n=4$; $24 \%)$, qualified teachers $(n=2 ; 12 \%)$, and the remainder $(n=7 ; 41 \%)$ of participants had unspecified or unclear teacher qualifications. About $53 \%(n=9)$ of the programs were for degree purposes and the remainder $(n=8)$ for professional development.

Study designs varied, using quantitative $(n=7,41 \%)$, qualitative $(n=8,47 \%)$, and mixed methods designs ( $n=2,12 \%)$. Analysis using the NHMRC levels (Merlin et al., 2009) of evidence found predominantly low quality of research designs. One study $(6 \%)$ was on level III- 1 , one (6\%) on level III-3, and seven $(41 \%)$ on level IV. mLearning was the focus of $29 \%(n=5)$ of the included studies, while $65 \%(n=11)$ reported on eLearning and $6 \%(\mathrm{n}=1)$ on video learning. All the reports were in English, as per the search criteria, however, one reported that their research was conducted in various dialects in India and reported in English.

Table 1: Data extraction worksheet

\begin{tabular}{|c|c|c|c|c|c|c|c|}
\hline \multicolumn{8}{|c|}{ Source: Article and reference } \\
\hline \multicolumn{8}{|c|}{ Population } \\
\hline Country & $\begin{array}{l}\text { Teaching } \\
\text { Context }\end{array}$ & $\begin{array}{c}\text { Partici- } \\
\text { pants }\end{array}$ & $\begin{array}{l}\text { Training } \\
\text { Program }\end{array}$ & $\begin{array}{l}\text { Age of } \\
\text { Children }\end{array}$ & $\begin{array}{l}\text { Teacher } \\
\text { Trainin } \\
\text { g }\end{array}$ & $\begin{array}{l}\text { Type of } \\
\text { Program }\end{array}$ & $\begin{array}{l}\text { Type of } \\
\text { Learning }\end{array}$ \\
\hline \multicolumn{8}{|c|}{$\begin{array}{l}\text { 1. A Teacher Tablet Toolkit to meet the challenges posed by 21st century rural } \\
\text { teaching and learning environments (Botha \& Herselman, 2015) }\end{array}$} \\
\hline $\begin{array}{l}\text { South } \\
\text { Africa }\end{array}$ & $\begin{array}{l}\text { Resource } \\
\text { con- } \\
\text { strained }\end{array}$ & 225 & Part Time & $6-18$ yo & $\begin{array}{l}\text { Teacher } \\
\text { (qualifi- } \\
\text { cation } \\
\text { unclear) }\end{array}$ & $\begin{array}{l}\text { Professional } \\
\text { Development }\end{array}$ & mLearning \\
\hline \multicolumn{8}{|c|}{$\begin{array}{l}\text { 2. e-Portfolio as reflective tool during teaching practice: The interplay between } \\
\text { contextual and dispositional variables (Carl \& Strydom, 2017) }\end{array}$} \\
\hline $\begin{array}{l}\text { South } \\
\text { Africa }\end{array}$ & $\begin{array}{c}\text { Not } \\
\text { reported }\end{array}$ & 11 & Part Time & 6-18 yo & $\begin{array}{l}\text { Student } \\
\text { teachers }\end{array}$ & $\begin{array}{l}\text { For degree } \\
\text { purposes }\end{array}$ & mLearning \\
\hline
\end{tabular}




\begin{tabular}{|c|c|c|c|c|c|c|c|}
\hline $\begin{array}{l}\text { South } \\
\text { Africa }\end{array}$ & $\begin{array}{c}\text { Not } \\
\text { reported }\end{array}$ & 47 & Full Time & $6-18$ yo & $\begin{array}{l}\text { Novice } \\
\text { teachers }\end{array}$ & $\begin{array}{c}\text { For degree } \\
\text { purposes }\end{array}$ & eLe \\
\hline
\end{tabular}

4. ODL students' perceived computer literacy competencies, expectations of support, intention to use and perseverance (Esterhuizen et al., 2012)

\begin{tabular}{|c|c|c|c|c|c|c|c|}
$\begin{array}{c}\text { South } \\
\text { Africa }\end{array}$ & $\begin{array}{c}\text { Not } \\
\text { reported }\end{array}$ & 332 & Part Time & $6-18$ yo & $\begin{array}{c}\text { Mixed } \\
\text { group }\end{array}$ & $\begin{array}{c}\text { For degree } \\
\text { purposes }\end{array}$ & eLearning \\
\hline
\end{tabular}

5. Using Self-Efficacy to measure primary school teachers' perception of ICT: results from two studies (Fanni et al., 2013)

\begin{tabular}{c|c|c|c|c|c|c|c}
$\begin{array}{c}\text { South } \\
\text { Africa, } \\
\text { Brazil }\end{array}$ & $\begin{array}{c}\text { Resource } \\
\text { con- } \\
\text { strained }\end{array}$ & 110 & Part Time & $6-13$ yo & $\begin{array}{c}\text { Teacher } \\
\text { (qualifi- } \\
\text { cation } \\
\text { unclear) }\end{array}$ & $\begin{array}{c}\text { Professional } \\
\text { Development }\end{array}$ & eLearning \\
\hline
\end{tabular}

6. Influence of mobile learning training on pre-service social studies teachers' technology and mobile phone self efficacies (Gloria \& Oluwadara, 2016)

\begin{tabular}{|c|c|c|c|c|c|c|c|}
\hline Nigeria & $\begin{array}{c}\text { Not } \\
\text { reported }\end{array}$ & 103 & Full Time & $6-18$ yo & $\begin{array}{c}\text { Student } \\
\text { teachers }\end{array}$ & $\begin{array}{c}\text { For degree } \\
\text { purposes }\end{array}$ & mLearning \\
\hline
\end{tabular}

7. App-supported promotion of child growth and development by community health workers in Kenya: Feasibility and acceptability study (van Heerden et al., 2017)

\begin{tabular}{c|c|c|c|c|c|c|c|} 
Kenya & $\begin{array}{c}\text { Resource } \\
\text { con- } \\
\text { strained }\end{array}$ & 26 & Part Time & $3-6$ yo & $\begin{array}{c}\text { Not } \\
\text { specifie } \\
\mathrm{d}\end{array}$ & $\begin{array}{c}\text { Professional } \\
\text { Development }\end{array}$ & mLearning \\
\hline
\end{tabular}

8. Workload and interaction: Unisa's signature courses - A design template for transitioning to online DE? (Hülsmann \& Shabalala, 2016)

\begin{tabular}{|c|c|c|c|c|c|c|c|}
\hline $\begin{array}{c}\text { South } \\
\text { Africa }\end{array}$ & $\begin{array}{c}\text { Not } \\
\text { reported }\end{array}$ & N/A & Part Time & $6-18$ yo & $\begin{array}{c}\text { Not } \\
\text { specifie } \\
\mathrm{d}\end{array}$ & $\begin{array}{c}\text { For degree } \\
\text { purposes }\end{array}$ & eLearning \\
\hline
\end{tabular}

9. Meeting teacher expectations in a DL professional development programme - a case study for the sustained applied competence as programme outcome (Kruger et al., 2016)

\begin{tabular}{|c|c|c|c|c|c|c|c|}
$\begin{array}{c}\text { South } \\
\text { Africa }\end{array}$ & $\begin{array}{c}\text { Not } \\
\text { reported }\end{array}$ & 50 & Part Time & 6-18 yo & $\begin{array}{c}\text { Teacher } \\
\text { (qualifi- } \\
\text { cation } \\
\text { unclear) }\end{array}$ & $\begin{array}{c}\text { Professional } \\
\text { Development }\end{array}$ & eLearning \\
\hline
\end{tabular}

10. Learning design in diverse institutional and cultural context: suggestions from a participatory workshop with higher education professionals in Africa (Mittelmeier et al., 2018)

\begin{tabular}{c|c|c|c|c|c|c|c}
$\begin{array}{c}\text { Kenya, } \\
\text { Uganda, } \\
\begin{array}{c}\text { Ghana, } \\
\text { Mozambiq } \\
\text { ue, South } \\
\text { Africa }\end{array}\end{array}$ & $\begin{array}{c}\text { Not } \\
\text { reported }\end{array}$ & 34 & $\begin{array}{c}\text { Not } \\
\text { Reported }\end{array}$ & $6-18$ yo & $\begin{array}{c}\text { Mixed } \\
\text { group }\end{array}$ & $\begin{array}{c}\text { Professional } \\
\text { Development }\end{array}$ & eLearning \\
\hline
\end{tabular}

11. Implications of the University of South Africa's (UNISA) shift to open distance eLearning on teacher education (Ngubane-Mokiwa, 2017)

\begin{tabular}{|c|c|c|c|c|c|c|c|}
$\begin{array}{c}\text { South } \\
\text { Africa }\end{array}$ & $\begin{array}{c}\text { Not } \\
\text { reported }\end{array}$ & N/A & Part Time & $6-18$ yo & $\begin{array}{c}\text { Mixed } \\
\text { group }\end{array}$ & $\begin{array}{c}\text { For degree } \\
\text { purposes }\end{array}$ & eLearning \\
\hline
\end{tabular}

12. Assessment of the problems postgraduate students face in accessing e-resources at Makerere University, Uganda: A comparison between education and LIS students (Okello-Obura, 2011)

\begin{tabular}{|c|c|c|c|c|c|c|c|} 
Uganda & $\begin{array}{c}\text { Not } \\
\text { reported }\end{array}$ & 25 & Part Time & $6-18$ yo & $\begin{array}{c}\text { Qualifie } \\
\mathrm{d} \\
\text { teachers }\end{array}$ & $\begin{array}{c}\text { For degree } \\
\text { purposes }\end{array}$ & eLearning \\
\hline
\end{tabular}




\begin{tabular}{|c|c|c|c|c|c|c|c|}
\hline \multicolumn{8}{|c|}{$\begin{array}{l}\text { 13. Using the mTSES to evaluate and optimize mLearning professional development } \\
\text { (Power et al., 2016) }\end{array}$} \\
\hline $\begin{array}{c}\text { Africa, } \\
\text { Asia, } \\
\text { Australia, } \\
\text { New } \\
\text { Zealand, } \\
\text { Europe, } \\
\text { North } \\
\text { America }\end{array}$ & $\begin{array}{l}\text { Not } \\
\text { reported }\end{array}$ & 37 & Part Time & 6-18 yo & $\begin{array}{l}\text { Mixed } \\
\text { group }\end{array}$ & $\begin{array}{c}\text { Professional } \\
\text { Development }\end{array}$ & mLearning \\
\hline \multicolumn{8}{|c|}{$\begin{array}{l}\text { 14. Mediated authentic video: A flexible tool supporting a developmental approach to } \\
\text { teacher education (Stutchbury \& Woodward, 2017) }\end{array}$} \\
\hline $\begin{array}{c}\text { India, } \\
\text { Bangladesh } \\
\text {, Peru, } \\
\text { Ghana }\end{array}$ & $\begin{array}{c}\text { Not } \\
\text { reported }\end{array}$ & N/A & Part Time & 6-18 yo & $\begin{array}{l}\text { Teacher } \\
\text { (qualifi- } \\
\text { cation } \\
\text { unclear) }\end{array}$ & $\begin{array}{c}\text { Professional } \\
\text { Development }\end{array}$ & Video \\
\hline \multicolumn{8}{|c|}{$\begin{array}{l}\text { 15. Development of ODL in a newly industrialized country according to face-to-face } \\
\text { contact, ICT, and e-Readiness (van Zyl et al., 2013) }\end{array}$} \\
\hline $\begin{array}{l}\text { South } \\
\text { Africa }\end{array}$ & $\begin{array}{l}\text { Not } \\
\text { reported }\end{array}$ & 87 & Part Time & 6-13 yo & $\begin{array}{c}\text { Qualifie } \\
\mathrm{d} \\
\text { teachers }\end{array}$ & $\begin{array}{c}\text { For degree } \\
\text { purposes }\end{array}$ & eLearning \\
\hline \multicolumn{8}{|c|}{$\begin{array}{l}\text { 16. Massive Open Online Courses (MOOCs) for professional teacher and teacher } \\
\text { educator development: a case of TESSA MOOC in Kenya (Wambugu, 2018) }\end{array}$} \\
\hline Kenya & $\begin{array}{c}\text { Not } \\
\text { reported }\end{array}$ & 47 & Part Time & 6-18 yo & $\begin{array}{l}\text { Teacher } \\
\text { (qualifi- } \\
\text { cation } \\
\text { unclear) }\end{array}$ & $\begin{array}{c}\text { Professional } \\
\text { Development }\end{array}$ & eLearning \\
\hline \multicolumn{8}{|c|}{$\begin{array}{l}\text { 17. Assessing the utilization level of e-Learning resources among ODL based pre- } \\
\text { service teacher trainees (Olaniran et al., 2017) }\end{array}$} \\
\hline $\begin{array}{l}\text { South } \\
\text { Africa }\end{array}$ & $\begin{array}{c}\text { Not } \\
\text { reported }\end{array}$ & 144 & Part Time & 6-13 yo & $\begin{array}{l}\text { Student } \\
\text { teachers }\end{array}$ & $\begin{array}{l}\text { For degree } \\
\text { purposes }\end{array}$ & eLearning \\
\hline
\end{tabular}

\subsection{Recommendations for Usability}

Nineteen recommendations for usability were identified while inductively grouping together the categories identified under each of the usability criteria presented below. These recommendations are summarised in in Table 2. Each of the recommendations were found to potentially be informed by multiple aspects of usability. The 19 unique recommendations were each supported by three or more of the 17 sources and, therefore, confirms the trustworthiness of the analysis. It also suggests that usability must be viewed as a single concept.

Table 2: Recommendations for usability

Design recommendations for usability of mLearning modules for preschool teachers in LMIC's

1. The design of mLearning modules should incorporate the enhancement of digital literacy skills through participation in the module. (Botha \& Herselman, 2015; Carl \& Strydom, 2017; Dreyer, 2017; Esterhuizen et al., 2012; Fanni et al., 2013; Gloria \& Oluwadara, 2016; van Heerden et al., 2017; Hülsmann \& Shabalala, 2016; Ngubane-Mokiwa, 2017; Okello-Obura, 2011; Olaniran et al., 2017; Power et al., 2016; Stutchbury \& Woodward, 2017; van Zyl et al., 2013; Wambugu, 2018)

2. The design should encourage participation in mLearning and computer literacy should be included as part of the curriculum for all teacher training (Dreyer, 2017; Esterhuizen et al., 2012; van Heerden et al., 2017; Hülsmann \& Shabalala, 
2016; Kruger et al., 2016; Ngubane-Mokiwa, 2017; Okello-Obura, 2011; Power et al., 2016; Wambugu, 2018)

3. The design should encourage participation in mLearning, through factors like gamification and positive feedback. (Botha \& Herselman, 2015; Esterhuizen et al., 2012; Gloria \& Oluwadara, 2016; van Heerden et al., 2017; Kruger et al., 2016; Power et al., 2016)

4. Continuous and scaffolded training of digital literacy should be incorporated in mLearning modules to encourage the effective adoption of technology in teaching in the classroom. (Botha \& Herselman, 2015; Dreyer, 2017; Esterhuizen et al., 2012; Gloria \& Oluwadara, 2016; van Heerden et al., 2017; Kruger et al., 2016; Mittelmeier et al., 2018; Ngubane-Mokiwa, 2017; Okello-Obura, 2011; Olaniran et al., 2017; Power et al., 2016; van Zyl et al., 2013; Wambugu, 2018)

5. mLearning modules should carefully scaffold the teaching of skills to accommodate all levels of competency, to improve motivation and skill to ultimately use devices for teaching. (Botha \& Herselman, 2015; Carl \& Strydom, 2017; Dreyer, 2017; Esterhuizen et al., 2012; Gloria \& Oluwadara, 2016; van Heerden et al., 2017; Kruger et al., 2016; Olaniran et al., 2017; Power et al., 2016; Stutchbury \& Woodward, 2017; van Zyl et al., 2013; Wambugu, 2018)

6. It should promote the use of smart phones as personal devices, professional devices and collaborative tools to improve the competency and perception of the teacher to ultimately use technology as a teaching aid. (Botha \& Herselman, 2015; Carl \& Strydom, 2017; Dreyer, 2017; Esterhuizen et al., 2012; Gloria \& Oluwadara, 2016; Hülsmann \& Shabalala, 2016; Olaniran et al., 2017; Power et al., 2016; Stutchbury \& Woodward, 2017; van Zyl et al., 2013; Wambugu, 2018)

7. mLearning should carefully scaffold both the knowledge content and literacy skills, to ensure success in achieving learning outcomes. (Mittelmeier et al., 2018; van Zyl et al., 2013; Wambugu, 2018)

8. mLearning modules should acknowledge achieved competencies and individual growth through use of the programme. (Botha \& Herselman, 2015; Carl \& Strydom, 2017; Esterhuizen et al., 2012; Gloria \& Oluwadara, 2016; van Heerden et al., 2017; Kruger et al., 2016; Power et al., 2016; Stutchbury \& Woodward, 2017; van Zyl et al., 2013; Wambugu, 2018)

9. Continuous support through online guides should be incorporated in the design of mLearning modules. (Carl \& Strydom, 2017; Dreyer, 2017; Esterhuizen et al., 2012; van Heerden et al., 2017; Hülsmann \& Shabalala, 2016; NgubaneMokiwa, 2017; Okello-Obura, 2011)

10. Continuous support through instant feedback should be part of the mLearning design to encourage perseverance in achieving digital literacy. (Carl \& Strydom, 2017; Esterhuizen et al., 2012; Gloria \& Oluwadara, 2016; Hülsmann \& Shabalala, 2016; Kruger et al., 2016; Ngubane-Mokiwa, 2017; Okello-Obura, 2011; Power et al., 2016)

11. mLearning modules should incorporate visual cues and visually orientated instruction aids, to promote intuitive use. (Carl \& Strydom, 2017; Esterhuizen et al., 2012; Okello-Obura, 2011)

12. Cognitive load should be considered with the design of a mLearning module. (Botha \& Herselman, 2015; Carl \& Strydom, 2017; Dreyer, 2017; Esterhuizen et al., 2012; Gloria \& Oluwadara, 2016; Kruger et al., 2016; Mittelmeier et al., 2018; Okello-Obura, 2011; Olaniran et al., 2017; Power et al., 2016; Stutchbury \& Woodward, 2017; van Zyl et al., 2013; Wambugu, 2018) 
13. Content should add value to classroom practices within user context as well as be usable within their context (Esterhuizen et al., 2012; van Heerden et al., 2017; Kruger et al., 2016; Stutchbury \& Woodward, 2017)

14. mLearning modules, especially with video content, should be customizable for different regions. (Esterhuizen et al., 2012; Kruger et al., 2016; Mittelmeier et al., 2018; Stutchbury \& Woodward, 2017)

15. Design should be for mobile devices and thus mLearning specifically. (Carl \& Strydom, 2017; Dreyer, 2017; Esterhuizen et al., 2012; Fanni et al., 2013; Gloria \& Oluwadara, 2016; Kruger et al., 2016; Mittelmeier et al., 2018; Ngubane-Mokiwa, 2017; Okello-Obura, 2011; Power et al., 2016; van Zyl et al., 2013; Wambugu, 2018)

16. The design should consider access to smartphones and tablets, which includes aspects like screen size and it's ubiquitous nature (Carl \& Strydom, 2017; Esterhuizen et al., 2012; Mittelmeier et al., 2018; Ngubane-Mokiwa, 2017; van Zyl et al., 2013)

17. The design should consider infrastructure constraints like access to data, the cost of data and access to consistent and reliable electricity as well as any other constraints (Botha \& Herselman, 2015; Esterhuizen et al., 2012; van Heerden et al., 2017; Mittelmeier et al., 2018; Ngubane-Mokiwa, 2017; Olaniran et al., 2017)

18. End users' context and constraints need to be considered for sustainability through heuristic and usability testing of mLearning modules. (Botha \& Herselman, 2015; Carl \& Strydom, 2017; Esterhuizen et al., 2012; Mittelmeier et al., 2018; Wambugu, 2018)

19. Usability and heuristic evaluation should be part of the design process (Botha \& Herselman, 2015; Dreyer, 2017; Esterhuizen et al., 2012; van Heerden et al., 2017; Kruger et al., 2016; Mittelmeier et al., 2018; Ngubane-Mokiwa, 2017; Power et al., 2016; Wambugu, 2018)

\section{Discussion}

This project mapped and summarized the peer reviewed literature on eLearning and mLearning of preschool teachers and day care providers in Africa, in order to develop recommendations for future mobile teacher training. No usability studies were identified. In addition, although 236 studies appeared appropriate when we completed the title screening, application of the inclusion criteria in abstract and then full-text screening yielded only 17 studies. Only these 17 studies included all four elements of (i) training of (ii) preschool teachers using (iii) any form of electronic learning (iv) in Africa. The literature included for this review was published in the last 10 years. However, over $70 \%$ of these research articles were published between 2016 and 2019, which is consistent with eLearning and mLearning being emerging fields in higher education (Kaliisa \& Picard, 2017). The design recommendations in Table 2, collectively inform the design of mLearning modules for preschool teacher training, specifically to improve usability. The 19 unique recommendations that collectively inform all aspects of usability are in agreement with current research which points to individual attributes not being factors of usability, but in fact, usability being a single concept (Lewis \& Sauro, 2017).

Regarding the quality of the nine studies in this review that employed mixed methods and quantitative methods, almost $80 \%$ were on level IV, which indicates 
that there is a lack of high quality, rigorous quantitative studies within eLearning and mLearning of teachers and day care providers in Africa. The research on the eLearning and mLearning of teachers of 3-6-year-olds exclusively, was limited to one included study. Teachers in Africa across all qualification levels from undergraduate to postgraduate, engage in eLearning and mLearning. This is largely on a part-time basis, however, was found to be for both professional development and for degree purposes. However, no studies were found that explicitly included day care providers solely with secondary education or no formal training.

Teachers within the African context expressed a need for contextual relevance in order to have a more sustainable impact on classroom practices through skill acquisition. This is consistent with a study done by Ackerman (2017) in the USA that investigated the characteristics of participants in online training for day care providers. In that study, online training met the needs of participants who desired the affordability, geographical accessibility, and ubiquitous nature of mLearning. The current study's results differed from Ackerman's (2017) in that their online courses were mostly on a beginner level and focused on knowledge acquisition, whereas the participants in the included studies indicated a need for courses that also bring about sustainable changes in classroom practices.

Teachers expressed a need for contextual relevance, not only in using training applications within their own context, but also in being able to change the content, like videos, to suit each region, and be of value and applicability within their classrooms. They also voiced their need for contextual relevance through sustainability of training and sustainability of change in classroom practice. Lavoie (2006) concludes that there is a lack of conceptual models to develop more context-aware mobile applications and that one way of ensuring contextual relevance is through user centred design. Thus, contextual relevance must be included as an attribute when developing a framework for usability within the African context for the assessment of mobile training applications. Usability testing is one step in the design cycle of mLearning training modules for teachers. Various studies indicated the need for heuristic and usability evaluation to ensure user centred design and usefulness.

Resource constraints of teachers and student teachers in Africa include inconsistent access to data, high cost of data, unreliable electricity supply, and limited access to computers. Therefore, mobile devices are preferred over eLearning or computer-based learning. Teachers in this review were motivated to learn how to use their cell phones better, progressing from use as personal device only to professional device, collaborative device, and finally as a teaching tool. This is consistent with the finding of Baran (2014) who concluded that among student teachers, mLearning holds the greatest possibility for collaborative, contextualized, customized, and personalized opportunities for learning. Teachers in Baran's (2014) study were also motivated to use mobile phones as both professional devices and teaching tools. 


\section{Practical Implications}

This scoping review has confirmed the limited available peer reviewed literature on mLearning for preschool teachers and day care providers in Africa in the last 10 years. Gaps within the research are two-fold, namely the lack of high-quality quantitative studies, as well as studies on mLearning for preschool teachers and day care providers specifically. This suggests a need for further research in both areas. From the limited data available it was clear that, in order to achieve user centred design and contextual value, heuristic evaluation and usability testing must be part of the design process for mLearning modules for preschool teachers and day care providers in Africa.

It is suggested that the integrated set of 19 unique usability recommendations developed from this review are included in the design process of future mLearning modules for preschool teachers and day care providers in Africa. Enhancing usability is important to maximise the impact of training programs on teachers' knowledge and skills, as well as to ensure the quality of these training modules and to reach the intended learning outcomes. This research also emphasises the importance of contextual relevance in the content of training programs, and the adaptation of learning materials for the local environment where learning will be applied. Contextually relevant learning increases the likelihood of mLearning being transferred to classroom practices.

\section{Limitations}

Two limitations were identified during this review process. Firstly, it was difficult to determine the level of consistency of key terms such as day care provider, since it is a term that varies from region to region and is also inconsistently used within the literature. The intent was to refer to someone who takes care of preschoolers (3-6-year-olds), on a formal or informal basis, and who is not required to be trained. This could then also include grandparents, neighbours, or untrained teachers. Secondly, knowledge users such as policy makers, preschool teachers and day care providers were not included in the development of the scoping review protocol, as suggested by the PRISMA-ScR reporting guidelines (Tricco et al., 2018).

\section{References}

Ackerman, D. J. (2017). Online child care training in the United States: A preliminary investigation of who participates, what is offered, and on which topics the workforce is focusing. International Journal of Child Care and Education Policy, 11(1), 1-22. https://doi.org/10.1186/s40723-017-0037-7

Arksey, H., \& O'Malley, L. (2005). Scoping studies: Towards a methodological framework. International Journal of Social Research Methodology, 8(1), 19-32. https:// doi.org/10.1080/1364557032000119616

Atmore, E., van Niekerk, L. J., \& Ashley-Cooper, M. (2012). Challenges Facing the Early Childhood Development Sector in South Africa. South African Journal of Childhood Education, 2(2), 120-139. https://doi.org/10.4102/sajce.v2i1.25

Baran, E. (2014). A Review of Research on Mobile Learning in Teacher Education. Journal of Educational Technology $\mathcal{E} \quad$ Society, 17(4), 17-32. http://www.jstor.org/stable/jeductechsoci.17.4.17

Barnett-Page, E., \& Thomas, J. (2009). Methods for the synthesis of qualitative research: A 
critical review. BMC Medical Research Methodology, 9(1), 1-11. https://doi.org/10.1186/1471-2288-9-59

Botha, A., \& Herselman, M. (2015). A Teacher Tablet Toolkit to meet the challenges posed by 21st century rural teaching and learning environments. South African Journal of Education, 35(4), 1-19. https:// doi.org/10.15700/saje.v35n4a1218

Carl, A., \& Strydom, S. (2017). e-Portfolio as reflection tool during teaching practice: The interplay between contextual and dispositional variables. South African Journal of Education, 37(1), 1-10. https:// doi.org/10.15700/saje.v37n1a1250

Chikwiri, E., \& Musiyiwa, J. (2017). Challenges and gaps in children's transition from early childhood development to grade one in Zimbabwe. International Journal of Educational Administration and Policy Studies, 9(7), 91-102. https://doi.org/10.5897/IJEAPS2017.0510

Davids, M. R., Chikte, U. M. E., \& Halperin, M. L. (2011). Development and evaluation of a multimedia e-learning resource for electrolyte and acid-base disorders. Advances in Physiology Education, 35(3), 295-306. https://doi.org/10.1152/advan.00127.2010

Davids, M. R., Chikte, U. M. E., \& Halperin, M. L. (2013). An efficient approach to improve the usability of e-learning resources: The role of heuristic evaluation. Advances in Physiology Education, 37(3), 242-248. https://doi.org/10.1152/advan.00043.2013

Davids, M. R., Halperin, M. L., \& Chikte, U. M. E. (2015). Optimising cognitive load and usability to improve the impact of e-learning in medical education. African Journal of Health Professions Education, 7(2), 147. https://doi.org/10.7196/ajhpe.659

De Wit, M., \& Plastow, N. A. (2021). Usability of eLearning interventions for teachers and day care workers in Africa: A scoping review protocol. South African Journal of Occupational Therapy, 50(3), 60-63. https://doi.org/10.17159/23103833/2020/vol50no3a7

Department of Basic Education. (2018). Human Resources Development Strategy for Early Childhood Development. https:// www.education.gov.za/Portals/0/Documents/Publications/4.pdf?ver =2020-03-09-141936-040

Dreyer, L. M. (2017). Digital storytelling to engage postgraduates in reflective practice in an emerging economy. South African Journal of Education, 37(4), 1-10. https:// doi.org/10.15700/saje.v37n4a1475

Dumas, J. S., \& Salzman, M. C. (2006). Usability assessment methods. Reviews of Human Factors and Ergonomics, 2(1), 109-140. https://doi.org/10.1177/1557234×0600200105

Esterhuizen, H. D., Ellis, S. M., \& Els, C. J. (2012). ODL students' perceived computer literacy competencies, expectations of support intention to use and perseverance. Turkish Online Journal of Distance Education, 13(4), 76-94. https://dergipark.org.tr/en/download/article-file/155967

Fanni, F., Rega, I., \& Cantoni, L. (2013). Using self-efficacy to measure primary school teachers' perception of ICT: Results from two studies. International Journal of Education and Development Using ITC, 9(1), 100-111. http:/ /ijedict.dec.uwi.edu//viewarticle.php?id=1528

Gloria, A., \& Oluwadara, A. (2016). Influence of mobile learning training on pre-service social studies teachers' technology and mobile phone self-efficacies. Journal of Education and Practice, 7(2), 74-79. https://eric.ed.gov/?id=EJ1089740

GMSA. (2020). The mobile economy: Sub-Saharan Africa 2020. https://www.gsma.com/mobileeconomy/wpcontent/uploads/2020/09/GSMA_MobileEconomy2020_SSA_Eng.pdf

Hannaway, D., Govender, P., Marais, P., \& Meier, C. (2018). Growing early childhood 
education teachers in rural areas. Africa Education Review, 16(3), 36-53. https:// doi.org/10.1080/18146627.2018.1445974

Heckman, J. J., \& Karapakula, G. (2019). Intergenerational and intragenerational externalities of the Perry Preschool Project. NBER Working Paper No. 25889, 53(9), 1-27. https://doi.org/10.3386/w25889

Hülsmann, T., \& Shabalala, L. (2016). Workload and interaction: Unisa's signature courses - a design template for transitioning to online DE? Distance Education, 37(2), 224236. https:// doi.org/10.1080/01587919.2016.1191408

International Organization for Standardization (2011). ISO/IEC 25010:2011, Systems and software engeneering - Systems and software Quality Requirements and Evaluation (SQuaRE) System and Software Quality Models. https:// pdfs.semanticscholar.org/57a5/b99eceff9da205e244337c9f4678b5b23d25 .pdf

Kaliisa, R., \& Picard, M. (2017). A systematic review on mobile learning in higher education: The African perspective. Turkish Online Journal of Educational Technology, 16(1), 1-18. https:/ / files.eric.ed.gov/fulltext/EJ1124918.pdf

Kruger, C., Janse Van Rensburg, O., \& de Witt, M. (2016). Meeting teacher expectations in a DL professional development programme - A case study for sustained applied competence as programme outcome. The International Review of Research in Open and Distributed Learning, 17(4). https://doi.org/10.19173/irrodl.v17i4.2458

Lavoie, M. C. (2006). I, MLearning: Identifying design recommendations for a contextaware mobile learning system. IADIS International Conference Mobile Learning, 265269. http://citeseerx.ist.psu.edu/viewdoc/summary?doi=10.1.1.95.1167

Levac, D., Colquhoun, H., \& O'Brien, K. K. (2010). Scoping studies: Advancing the methodology. Implementation Science, 5(69), 1-9. https://doi.org/10.1186/17485908-5-69

Lewis, J. R., \& Sauro, J. (2017). Revisiting the factor structure of the system usability scale. Journal of Usability Studies, 12(4), 183-192. https:/ / uxpajournal.org/revisit-factorstructure-system-usability-scale/

Manning, M., Garvis, S., Fleming, C., \& Wong, G. T. W. (2017). The relationship between teacher qualification and the quality of the early childhood education and care environment. Campbell Systematic Reviews, 13(1), 1-82. https://doi.org/10.4073/csr.2017.1

Mashburn, A. J., Pianta, R. C., Hamre, B. K., Downer, J. T., Barbarin, O. A., Bryant, D., Burchinal, M., Early, D. M., \& Howes, C. (2008). Measures of classroom quality in prekindergarten and children's development of academic, language, and social skills. Child Development, 79(3), 732-749. https://doi.org/10.1111/j.14678624.2008.01154.x

Merlin, T., Weston, A., \& Tooher, R. (2009). Extending an evidence hierarchy to include topics other than treatment: revising the Australian 'levels of evidence'. BMC Medical Research Methodology, 9(1), 1-8. https://doi.org/10.1186/1471-2288-9-34

Mittelmeier, J., Long, D., Cin, F. M., Reedy, K., Gunter, A., Raghuram, P., \& Rienties, B. (2018). Learning design in diverse institutional and cultural contexts: Suggestions from a participatory workshop with higher education professionals in Africa. Open Learning: The Journal of Open, Distance and e-Learning, 33(3), 250-266. https:// doi.org/10.1080/02680513.2018.1486185

Ngubane-Mokiwa, S. A. (2017). Implications of the University of South Africa's (UNISA) shift to open distance e-learning on teacher education. Australian Journal of Teacher Education, 42(9), 111-124. https://doi.org/10.14221/ajte.2017v42n9.7

Okello-Obura, C. (2011). Assessment of the problems LIS postgraduate students face in accessing e-resources in Makerere University, Uganda. Collection Building, 29(3), 
98-105. https:// doi.org/10.1108/01604951011060385

Olaniran, S. O., Duma, M. A. N., \& Nzima, D. R. (2017). Assessing the utilization level of e-learning resources among ODL based pre-service teacher trainees. Electronic Journal of e-Learning, 15(5), 384-394. https://files.eric.ed.gov/fulltext/EJ1157949.pdf

Park, Y. (2011). A pedagogical framework for mobile learning: Categorizing educational applications of mobile technologies into four types. The International Review of Research in Open and Distributed Learning, 12(2), 78-102. https://doi.org/10.19173/irrodl.v12i2.791

Power, R. L., Cristol, D., Gimbert, B., Bartoletti, R., \& Kilgore, W. (2016). Using the mTSES to evaluate and optimize mLearning professional development. The International Review of Research in Open and Distributed Learning, 17(4), 350-385. https:// doi.org/10.19173/irrodl.v17i4.2459

Ramey, C. T., \& Ramey, S. L. (2004). Early learning and school readiness: Can early intervention make a difference? Merrill-Palmer Quarterly, 50(4), 471-491. https://doi.org/10.1353/mpq.2004.0034

Smit, N. A., van der Linde, J., Eccles, R., Swanepoel, D. W., \& Graham, M. A. (2020). Exploring the knowledge and needs of early childhood development practitioners from a low-resource community. Early Childhood Education Journal, 49(2), 197-208. https://doi.org/10.1007/s10643-020-01063-3

Stutchbury, K., \& Woodward, C. (2017). Mediated authentic video: A flexible tool supporting a developmental approach to teacher education. Journal of Learning for Development, 4(2), 229-240. https:/ files.eric.ed.gov/fulltext/EJ1149176.pdf

Taat, M. S., \& Francis, A. (2020). Factors influencing the students' acceptance of e-learning at teacher education institute: An exploratory study in Malaysia. International Journal of Higher Education, 9(1), 133-141. https:// doi.org/10.5430/ijhe.v9n1p133

Tricco, A. C., Lillie, E., Zarin, W., O'Brien, K. K., Colquhoun, H., Levac, D., Moher, D., Peters, M. D., Horsley, T., Weeks, L., Hempel, S., Akl, E. A., Chang, C., McGowan, J., Stewart, L., Hartling, L., Aldcroft, A., Wilson, M. G., Garritty, C., . . Straus, S. E. (2018). PRISMA extension for scoping reviews (PRISMA-ScR): Checklist and explanation. Annals of Internal Medicine, 169(7), 467-473. https://doi.org/10.7326/m18-0850

van Heerden, A., Sen, D., Desmond, C., Louw, J., \& Richter, L. (2017). App-supported promotion of child growth and development by community health workers in Kenya: Feasibility and acceptability study. JMIR mHealth and uHealth, 5(12), e182. https:// doi.org/10.2196/mhealth.6911

van Zyl, J. M., Els, C. J., \& Blignaut, A. S. (2013). Development of ODL in a Newly Industrialized Country According to Face-to-Face Contact, ICT, and E-Readiness. International Review of Research in Open and Distance Learning, 14(1), 84-105. https://doi.org/10.19173/irrodl.v14i1.1342

Wambugu, P. W. (2018). Massive Open Online Courses (MOOCs) for professional teacher and teacher educator development: A case of TESSA MOOC in Kenya. Universal Journal of Educational Research, 6(6), 1153-1157. https://doi.org/10.13189/ujer.2018.060604

Zhang, D., \& Adipat, B. (2005). Challenges, methodologies, and issues in the usability testing of mobile applications. International Journal of Human-Computer Interaction, 18(3), 293-308. https://doi.org/10.1207/s15327590ijhc1803_3 